\title{
Cruel Choice: The Ethics and Morality of the Death Penalty
}

\author{
Ruth Endam Mbah ${ }^{1,2,3^{*}} \quad$ Tanisha Pruitt ${ }^{1,2,3}$ Divine Forcha Wasum ${ }^{4}$ \\ 1.International Center for IT and Development (ICITD), Southern University and A\&M, LA, USA \\ 2.Department of Public Policy, Southern University and A\&M, LA, USA \\ 3. Nelson Mandela Institute for Research (NMIR) \\ 4.Centre International De Formation Européenne, CIFE Nice/Berlin
}

\begin{abstract}
The death penalty, also known as capital punishment, has been and is still a highly debated issue in society. While many nations around the world have abolished the death penalty as a form of punishment, some nations still emphasize its importance as a valid means for punishing specific types of crimes. The purpose of this study is to investigate the impact of the death penalty on the families of the executed, families of the murder victim and the executed or murderer. This paper is an in-depth analysis of various facts and evidence focusing on the death penalty in the USA. Special attention is paid to the 31 states whose laws permit death penalty as a form of punishment. The evidence reviewed indicates that capital punishment impacts seriously all members of the families involved on both sides, victim and perpetrator, and the entire American society. Specifically, the evidence shows that most of the children of the executed face emotional and financial problems while some of them develop bitterness and an urge to revenge. Surprisingly, some victim family members regret accepting the execution of the murderer of their loved ones because it did not give them the healing they expected. The evidence also shows that some persons were wrongly murdered; a court of law declared their innocence and freed them from any law breaking several years after their execution. The implication is that because executing an innocent person is one too many, courts must be very cautious and not permitting any execution unless there is an overwhelming verifiable evidence that cannot be reversed.
\end{abstract}

Keywords: Death penalty, crime, execution, murder, victim

DOI: $10.7176 /$ RHSS/9-24-03

Publication date: December $31^{\text {st }} 2019$

\section{Background to the Death Penalty}

The criminal justice system is fixated on the tenets of crime and punishment. History shows us that the extent to crime and punishment is often grounded in ideologies that perpetuate a system of inequality and disparity. Like most institutions in American society there are winners and losers within the criminal justice, with families of victims tending to be the latter. According to Fraser, (2010) the criminal justice system is one part of American society that has been least affected by social progress that has otherwise transformed other areas of society. The lack of social progress is most visible in the practice of the death penalty. Notable sociologist, historian, and activist W.E.B. Du Bois, in his works on race and crime, gives a possible explanation to the lack of progress and continuing disparities within the criminal justice system, through his ideology on double standards and the color line (Gabbidon 2001).

Through his research Du Bois discovered that there exist double standards for African Americans in the criminal justice system. African Americans receive harsher penalties due to unfair sentencing practices and they often receive punishment without just cause. Du Bois discusses a possible explanation for this in his Seminole 1903 work, The Souls of Black Folk, could be the color line that exist between blacks and whites. The color line refers to a divide between races, often invisible but often physical (Du Bois 2007).

While the purpose of this paper is not to harp on the racial disparities in death penalty executions, it is important to note how race plays a major role in public opinion on the death penalty and the sentencing of the death penalty in American courts. Racial stimuli can have a substantial effect on white support for capital punishment (Peffley and Hurwitz 2007). With African Americans being disproportionately represented among death row inmates, African-Americans are inadvertently affected more by the death penalty.

Death penalty also known as Capital Punishment did not start today and is likely not ending any time soon. The Creator of the Universe in the days of Noah wiped off the entire human race as punishment for their sins but for Noah and his immediate family. The Hammurabi Code assigned different forms of punishments for various classes of crimes one of which was the death penalty. The first five books of the Bible (Pentateuch) or the Torah (Jewish Law) ascribed death penalty for various crimes like: non respect for the Sabbath, blasphemy, wide range of sexual crimes, kidnapping, magic, murder, witchcraft and many more (Schabas 2002). Also, death penalty was carried out for series of special crimes in Ancient Greece according to the Athenian legal system which was first written by Draco around 621BC (Anon n.d.). The Romans equally made use of death sentence as a form of punishment for several forms of crimes which even Jesus Christ the Messiah could not escape.

Before the advent of modern prison system, the death penalty was used as a general form of punishment in 
medieval and early modern Europe. Numerous as about 72000 persons were estimated to have been executed during the reign of Henry VIII of England. Between the $15^{\text {th }}$ and $18^{\text {th }}$ century in early modern Europe, there was an extensive spread of witchcraft operations perceived as an organized threat to Christendom in Europe and later in their North American Colonies. Due to this, tens of thousands of women accused of witchcraft were executed by the witch trial of the early modern period. The Buggery act of 1533 stipulated hanging as penalty for bugger in England and James Pratt and John Smith were the last to be executed for sodomy in 1835 (Cook et al. 2007).

With the advent of the modern and contemporary eras and the emergence of modern nation states, justice came to be progressively more associated with the ideology of natural and legal rights. Cesare Beccaria treaties on Crimes and Punishment 1764 were the first elaborated analysis of capital punishment to demand for the abolition of the death penalty (Wright 2009; Zimring 2003). The founder of modern utilitarianism, Jeremy Bentham also called for the abolition of death penalty (Bedau 1983). The $20^{\text {th }}$ century was seen as a violent period as tens of millions lost their lives in wars between nation-states as well as genocide. Four most notorious examples include; the Turkish assault on the Armenians, Hitler's attempt to exterminate the European Jews, the Khmer Rouge decimation of Cambodia, the Massacre of the Tutsis in Rwanda. In Nazi Germany, capital punishment was by hanging, decapitation and death by shooting (Dandō 1997) As a means to maintain military discipline, modern military organizations employ death penalty like the soviet execution of 158000 soldiers for desertion during WWII (Sheehan 2007). States with fascist or communist government (authoritarian regimes) as means of political oppression make use of the death penalty.

Mao Zendong publicly declared that ' 800000 ' people had been sentence to death after the victory of the Communist Party in 1949. These excesses have led to the increasing emphasis on the idea of human rights and the abolition of death penalty by civil rights organizations. All European (but for Belarus) and many Pacific Area States (including Timor Leste, New Zealand and Australia) and Canada have abolished capital punishment among countries of the world. Africa (like Botswana and Zambia), Guatemala, most of the Caribbean and majority of democracies in Asia (like Japan and India) and the United States (federal government and 32 states) retain it. South Africa Constitutional Court jointly abolished the death sentence on $6^{\text {th }}$ June 1995 in the judgment of the case state vs Makwanyara and Another (Sheehan 2007). The death penalty remains a highly debated issue but remains a cruel form of punishment executed through numerous devastating methods which in most opinions defiles the ethics and morality of human right.

\section{Methods of Death Penalty and Crimes Punishable by Death Penalty}

There have existed several cruel ways of effectuating death penalty over the years. Animals like elephants, alligators, crocodiles, piranha, sharks, snakes, scorpions, spiders have been used for execution. Back-breaking was a mongolian form of execution that avoided blood spilling. Boiling to death, Catherine wheel or breaking wheel, buried alive, burning, cooking, crucifixion, crushing, disembowelment, dismemberment, falling, flaying, garrote, gibbeting, immurement, impalement, keelhauling, poena cullei, poisoning, pendulum, sawing, scaphism, strangulation, asphyxia, starvation/dehydration, suffocation, thumbscrew and stoning are some of the terrific forms of execution that were used.

In the US, there exist five different forms of executions used by the 36 states practicing death penalty. Hanging was the principal method of execution in the USA until the 1890s (Anon n.d., Anon n.d.; Weisberg 1991). Lethal injection as a modern form of execution was first adopted in Oklahoma with Charles brooks as the first victim to be executed using it five years later in Texas on December 2, 1982. In present days, it is used by all of the US 32 states that practice death penalty (Weisberg 1991). Electrocution was introduced as a more human method than hanging as the first electric chair was built in New York in 1888 with William Kemmler as the first to be executed using this in 1890. Gas Chamber as another means considered to be humanistic was established by Nevada in 1924 and Gee Jon was the first to be executed via lethal gas (Bohm 1999). Firing Squad was reauthorized in Utah as a means of execution in the case where the state could not obtain drugs required for a lethal injection (Weisberg 1991). Nevertheless, remains the most used form currently.

Figure 1: Methods of Executions from 2015 to 2019

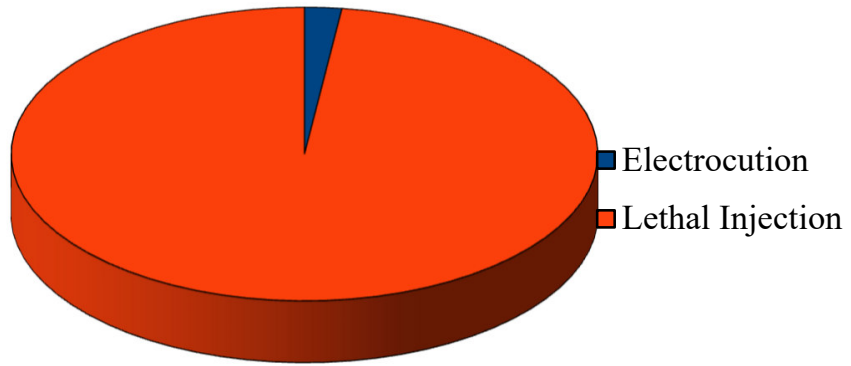

Source: Authors' calculations adapted from the Death Penalty Information Center, 2019 
In the USA, there is a list of 41 federal capital crimes that could lead to a criminal's death under the US Code (Anon 2012). Some of these include: murder that is related to the smuggling of aliens; death resulting from the destruction of aircraft or motor vehicles; murder committed during a drug-related drive-by shooting; murder committed at an international airport; retaliatory murder of a family member of law enforcement officials; civil rights offenses resulting in death, murder of a member of congress, executive or supreme court justice; espionage (Ethel and Julius Rosenberg were victims of this); death resulting from transportation of explosives, destruction of government property or during foreign commerce; murder with a firearm during drug trafficking offense; murder committed in a federal government facility; genocide; first-degree murder; murder of a foreign official, murder by a federal prisoner, murder during a kidnapping, assassinating or kidnapping the president or vice president, murder for hire, sexual abuses resulting to death; treason; just to name a few (Anon n.d.). 62 offenders were on the federal death row as of January 1, 2017 housed by the Federal bureau of Prisons. (Anon 2018). Despite all of these, there are views that condemn such a cruel choice of punishment.

\section{Death Penalty as a Cruel Choice: Views in Favor of the Abolition of Death Penalty}

Jeremy Bentham, principal expounder of Utilitarianism and author of the famous 'Principles of Morals and Legislation' was a force behind the abolishing of the death penalty in England. According to him, pain and pleasure were the two sovereign masters under which nature had placed mankind. Bentham in defining the principle of utility said "is meant that principle which approves or disapproves of every action whatsoever, according to the tendency which it appears to have to augment or diminish the happiness of the party whose interest is in question: or what is the same thing in order words, to promote or to oppose that happiness. I say of every action whatsoever; and therefore not only of every action of a private individual, but of every measure of government." (Benthany n.d.) This was meant to prevent happening of mischief, pain, evil or unhappiness to the party whose interest is considered.

This party was mostly the community which to him is the sum of the interest of the several individual persons that compose it. According to Bentham, there were four separate sources from which pain could come from: the physical, the political, the moral, and the religious. He goes further to pinpoint that pleasures and the avoidance of pains are the ends that the legislator has in view. He used his general principles of utilitarianism on punishment to criticize the death penalty as he intensively discussed in two chapters of Book II of his 'Rational of Punishment' and one of his last essays 'On death Punishment'. According to him the principal aim of punishment was to control action or general prevention. Thus, any justifiable punishment that should be adopted by any penal law is those that efficiently produce the greatest happiness. This happiness does not only involve lower crime rate but factors like the well-being of the persons being punished which death penalty does not consider.

As an alternative to death penalty, he suggested 'prison discipline' which he went ahead to precise that the imprisonment should be followed with hard labor and scarcely with solitary confinement in 1775 . He brought out four characteristics of punishment that appeal against the death penalty comparative to imprisonment: it is 'not convertible to profit', it lacks 'frugality', as well as 'equability', and it is 'not remissible'. He saw death penalty as unprofitable because the death convict cannot provide compensation as it does not repair the lost suffered by the victim of the crime or by society in bringing the offender to justice. His winning point was the fact that there is no remedy for death. It cannot be corrected if it was erroneously afflicted whereas imprisonment can be rectified by liberating the victim if he is later discovered to have been innocent. There is equally no way a death person can be compensated for an erroneous death penalty sentence whereas an unjust imprisonment can be compensated with money (Bedau 1983; Ebenstein and Ebenstein 2000).

More so, in disapproval of the death penalty, in 1980 the American Medical Association's Council on Ethical and Judicial Affairs and the World Medical Association one year after declared participation by doctors in legally authorized executions as unethical. A working party of the BMA issued a report on physicians and human rights, which validates the view that medical ethics forbids not only the act of injecting the lethal substance but also any complicity in the execution process. Even though to certify death is part of the duty of the medical field, the working party firmly advices that this should be done in a place away from the execution site so that the doctor will not be present at the execution. The 1992 Code of Medical Ethics, Article 2.06 explicitly prohibits any involvement in executions but for prescribing sedation beforehand and later signing the death certificate (British Medical Association 1992).

According to Dr. Philip B. Woodhall, M.D., of the emergency unit in North Carolina for many years, medicine and execution do not mix. To him medical powers are dedicated to the preservation of human life and not to the service of death. Also, American Medical Association (AMA) and the National Association of Emergency Medical Technicians (NAEMT) publicly issued statements to remind their members of their ethical obligations not to participate in legally authorized executions. AMA president William G. Plested III in respond to the continuous struggle of the courts and legislatures throughout the country on lethal injection said AMA clearly forbids medical professionals from involvement in any executions as it violates their oath to protect life and corrodes public confidence in the medical profession. Despite this opposition from the court and legislatures, as the voice of AMA, 
he calls on all physicians to stay committed to the ethics of their profession that prohibits involvement in death penalty. NAEMT is also strongly against the participation of an EMT, Paramedic or other emergency medical professional in death penalty (Death Penalty Information Center n.d.).

It is seen as contrary to their goals and ethical obligations as emergency medical service providers. Their oath is to save life, respect human life and non-infliction of harm to all recipients of emergency medical service care and should not be breached even when legally sanctioned (NAEMT 2010). The American Society of Anesthesiologists (ASA) president Dr. Orin Guidry urged his members through a public statement to 'Steer clear' of any involvement in executions by lethal injection. This statement came as U.S District Judge Fernando Gaitan $\mathrm{Jr}$ tried involving board certified anesthesiologist in the lethal injection procedure in Missouri. This is seen as a violation of AMA position which had been adopted by ASA despite the court's position on ethical obligation (Death Penalty Information Center n.d.). These medical bodies are backed and supported by human right advocated.

The UN General Assembly has called for the end of death penalty and human rights associations affirm this as it violates one of the key principles under human right law that recognizes the right to life. The Center for Constitutional Rights is committed in pushing forward and protecting the guaranteed rights by the Universal Declaration of Human Right (UDHR), which the US helped draft after WWII and adopted in 1948. Article 3 of the UDHR says life is a human right, making the death penalty a violation of the most principal human right. It is ironical that the US which assisted in drafting UDRH is still practicing the death penalty. The Center for Constitutional Rights joining the fight against the death penalty issued a paper entitled 'The US Tortures before it Kills: An Examination of the Death Row Experience from a Human Right Perspective' as it joined the rest of the world in commemorating the $9^{\text {th }}$ Annual World day Against the Death Penalty. It scrutinized life on death row including years of solitary detention with less human contact and the unbearable procedure of repeatedly coming within hours of execution (Dieter 1993).

Amnesty International is another strong advocate against death penalty as it violates human rights since 1977. According to Amnesty International, 'the death penalty is cruel, inhuman and degrading. Amnesty opposes the death penalty at all times-regardless of who is accused, the crime, guilty or innocent or method of execution.' Death penalty breaches two fundamental rights of humans: the right to live free from torture and the right to life. It argues that death penalty is irreversible, and mistakes happen like 150 US prisoners who had later been exonerated after haven been sent to the death row since 1973. To it, death penalty does not deter crime; it's often used within skewed justice systems like China, Iraq, Iran; it is often discriminatory and used as a political tool like in Sudan or Iran.

These international laws explicitly ban use of death penalty except during war times: The Second Optional Protocol to the International Covenant on Civil and Political Rights; Protocol No.6 to the European Convention on Human Rights; the Protocol to the American Convention on Human Rights to Abolish the Death Penalty. Protocol No. 13 of the European Convention on Human Right forbids death penalty at all times even during war time. Amnesty, despite the exceptions places by some international law for death penalty to be allowed on very serious crimes believes that it is never the answer to any form of crime (Anon n.d.). On December 19, 2016, the $71^{\text {st }}$ UN General Assembly on 'Moratorium on the use of the death penalty' adopted a sixth resolution (A/RES/71/187) with 117 countries voting in favor (United Nations 2018).

Various religious organizations around the world are not left out in the fight against death penalty. Pope Francis in his words to the International Commission against the death penalty who met in the Vatican on 02/20/2015 said "Capital punishment is cruel, inhuman and an offense to the dignity of human life. In today's world, the death penalty is 'inadmissible' however serious the crime' that has been committed" (Catholic Charities 2015). The pope thanked those involved in the universal moratorium with the goal of abolishing the use of death penalty as they continue to work relentlessly. Pope Francis also made it clear that killing another human being can never bring about justice and stressed on the fact there will never be a human way of administering the death penalty. For Christian he said that the life of every human is sacred because we are created by God who does not punish one murder by and another and who even seeks that a murderer should rather repent. He therefore frowns at the death penalty as it is oppose to divine mercy and he sees it as a failure on the part of any state because it can never bring justice to the victims but instead encourages revenge. ${ }^{31}$ The American Baptist Church sees the death penalty as morally unacceptable and a form of cruel and unusual punishment that is inconsistent with religious and ethical traditions. Life is sacred and there is an obligation to overcome evil with good as taught in the scriptures.

The General Board of the American Baptist Church recommended the abolition of capital punishment in those US states still practicing it and urged all its members to support the various bodies, agencies and groups fighting for its abolition in those government jurisdictions of the US where it is still authorized by law. To strengthen their stand, American Baptist Church published 'American Baptist Policy Statement on Human Right' in December 1976 which in summary included the right to human dignity and the right to be free from arbitrary arrest, detention and torture (Vgoff n.d.). The Ninth All-American Council of Orthodox Church in America equally supports the abolition of death penalty in America and all other countries and called on all state officials in the states practicing it to introduce and encourage appropriate legislation aimed at abolishing the death penalty. The 
council justified that even Jesus Christ Himself prevented the legal execution of a woman in John 8:3-11 and that premature death resulting from the application of the death penalty can prohibit the rehabilitation, reconciliation and redemption of the offender (Orthodox Church in America n.d.).

More so, in 1959 the $171^{\text {st }}$ General Assembly of the US Presbyterian Mission said death penalty cannot be condoned by an interpretation of the Bible based on the revelation of God's love in Jesus Christ and thus called on all Christians to seek the redemption of evil doers and not their death (Presbyterian Church USA n.d.). As the years went by, the assembly became stronger on its stand against death penalty. In 2010 it reaffirmed its stand against death penalty and called for 'an immediate moratorium of all executions in all jurisdictions that impose capital punishment.' (Presbyterian Church USA 2010). Death penalty is not only seen as a cruel choice by various agencies, groups and religious bodies but its seen in the pain the families of the executed go through.

\section{Reactions of the Family Members of the Murdered Victims on Death Penalty Punishment}

Psychologist Dr. Robert T. Muller recounted that psychological research has proven that the families and friends of the murder victim (co-victims) do not feel any better after the execution of the criminal but it rather has a negative effect on them. A research from University of Minnesota study found that just $2.5 \%$ of co-victims testified achieving closure as a result of death penalty, while $20.1 \%$ said the execution did not help them heal. This may be due to the fact that healing is a process not an even as reported by one of the co-victims. In 2012 a research study from Marquette University Law School showed that co-victims had greatly improved both physically and psychologically given that the murderer was rather given life sentence than death penalty by the law. More so, a Florida therapist, Lula Redmond who constantly works with family members of murder victim said "More often than not, families of murder victims do not experience the relief they expected to feel at the execution. Taking a life doesn't fill that void, but it's generally not until after the execution those families realize this. " (Muller. Robert 2016)

In 2014, when Jeff Ferguson was executed by Missouri for the rape and murder of Kelli Hall, the Hall family, her father said "believe the myth that Ferguson's execution would close our emotional wounds." During the execution Jim Hall told reporters "It's over, thank God." Today the story is different. The Hall family regret Ferguson's execution after the family viewed a documentary several weeks after the execution, "Potosi: God in Death Row," in which Ferguson regrets his act and the pain he caused both his family and the victim's. They also learned that Ferguson had been a leader in the prison's hospice, GED, and restorative justice programs, as well as one in which prisoners listened to victims share the devastating impact the crimes had on their lives. The Hall family forgave him and Mr. Hall said "my family wishes we had known of his involvement in these programs and been invited to participate. ... I'm convinced significant healing would have occurred for us all if our family had engaged in a frank conversation with him at the prison. I wish I had had the chance -- consistent with my Christian beliefs -- to have told him in person that I forgave him for what he did to our innocent and precious daughter." Columbia Daily Tribute has a record of Mr. Hall's statement where he writes that his family "come to deeply regret [Ferguson's] execution" and appeal to Governor Jay Nixon to commute the death sentences of the 25 men remaining on the state's death row (Hall 2016).

In the racially-motivated shooting at Charleston's Emanuel AME Church two year ago, Sharon Risher, lost her mother, Ethel Lance and cousins: Susie Jackson and Tywanza Sanders. Risher who is a church chaplain says she has not forgiven Dylann Roof, the accused perpetrator, but does not think he should be sentenced to death. Her sister unlike her voiced it publicly that she had forgiven Roof, few days after the shooting. Risher said "Despite the anger I am still coping with from my mother's death, I don't believe in the death penalty, even for the man who killed her. That's my conviction because of my faith. I don't believe as human beings that we should take away someone's life just because we have the power to do so" (Risher 2016).

Christy Sheppard was told by the police and prosecutors that her Cousin Debbie Carter's rape and murder criminals in Ada Oklahoma in 1982 were Ron Williamson and Dennis Fritz. Williamson was convicted and sentenced to death while Fritz received a life sentence in 1988 but were found innocent eleven years after when DNA testing excluded them as committers and pointed to another man who had once been a suspect. After discovering their innocence, Sheppard, now a criminal justice counselor and victim advocate in Ada in an article said "The guilt has been awful. It is horrible to think that you prayed, wished, helped and condoned to bring harm to someone else and then to find out that it wasn't deserved and later learn what they went through." Sheppard said her family was shocked, "It was like being in a Twilight Zone. It fit nothing we knew to be true." It changed her view on death penalty and she is now serving Oklahoma Death Penalty Review Commission, which is expected to make recommendations in 2017 on reforms to Oklahoma's death penalty (Hendee 2016).

Even with the objections of Ms. Farah's family, Duval County, Florida prosecutors are in search of the death penalty for the 2013 murder of Shelby Farah. After vain attempts to convince prosecutors to non-capitally resolve the case, Darlene Farah, Ms. Farah's mother, publicly voiced her views in a February 2016 column in TIME. Farah said, "I do not want my family to go through the years of trials and appeals that come with death-penalty cases." Instead, she wants her family to be able to, "celebrate [Shelby's] life, honor her memory and begin the lengthy 
healing process" (Farah 2016).

\section{Reactions of the Family Members of the Executed Criminal on Death Penalty Punishment}

The effect of the death penalty on the families especially the children of the executed is very devastating and at times builds in their kids a desire for revenge. The criminal justice systems of states still practicing the death penalty pay little attention to these consequences. The New York times examine the plight of the families of the executed in "Killers' Families Left to Confront Fear and Shame" record that in the flash of a depressing moment, they said their lives had become a vortex of guilt, anger and shame. Many said they were dumbfounded by the blame and snubbing they had received for crimes they had no part in (KCADP 2012).

Tania recounted her sad story at the Human Rights Council discussion on the human rights of children of parents sentenced to death or who have been executed in September 2013. She said "My name is Tania. I was born in prison ... and was delivered to my father the same day. Both my parents were political activists. In March 1984, when I was only one year old, the body of my 28 year old mother was delivered to our family and my father was sent into exile three days later. I have never experienced family life and as a young woman do not know what having a mother means... I personally urge all countries that have not yet ratified the Second Optional Protocol to the International Covenant on Civil and Political Rights to do so and I wish a day where no parents are executed and no child is left without the support of parents." Gerald Marshall a member of the European Association for Human Rights equally recounts his experience as he visited the Texas death row where he saw a little girl crying endlessly. She was less than 10years old and her father was about to be executed. Marshall continued to think about this little girl and her two brothers and says the death penalty creates even more victims: The Children of Executed Prisoners (United Nations Human Right 2013).

\section{Current updates on Execution Rates and Public Opinions in America on the Death Penalty}

Figure 2: No of Executions by States from 2015 to 2019

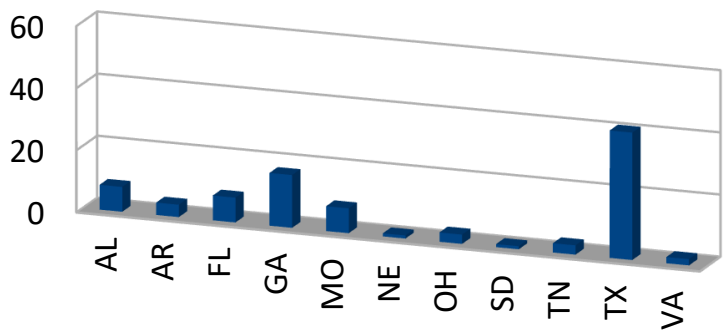

- No of Executions

Source: Authors' calculations adapted from the Death Penalty Information Center, 2019

Our calculations on execution from 2015 to 2019 based on the 2019 Death Penalty Information Center shows that Texas had 41 executions out of 96. 2015 had 29 executions, 2016 had 20, 2017 registered 23, 2018 had 25 while as of February 2019 only two executions have been registered so far. Just one female called Kelly Gissendaner was executed from 2015 to 2019. She was executed precisely on 9/30/2015. This statistics also showed that a majority of the murder victims were whites. Surprisingly, more whites (murderers) have been executed from 2015 to 2019 .

Figure 3 Ethnicity of those on Execution from 2015 to 2019

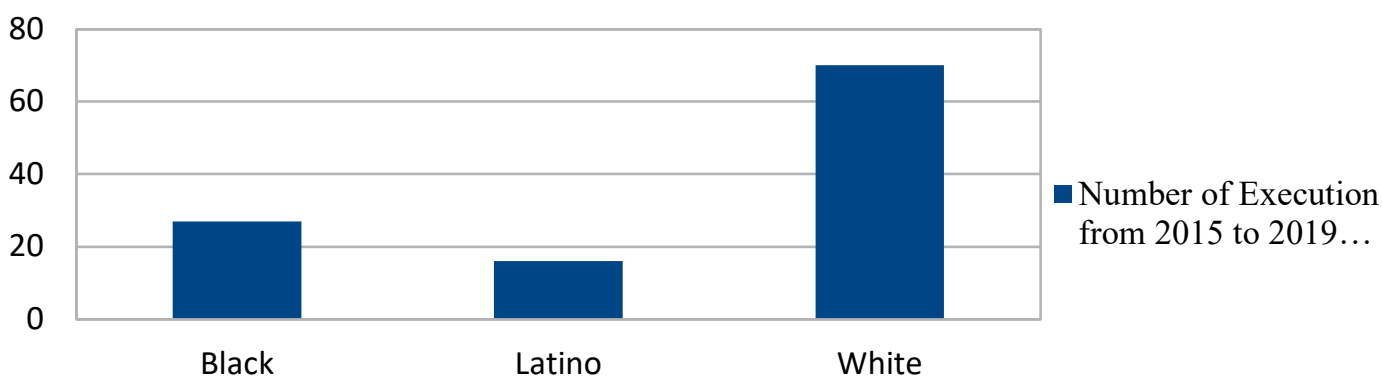

Source: Authors' calculations adapted from the Death Penalty Information Center, 2019

Though the death penalty is still legal in most of the US states, including two states- California and Nebraska where voters decided to retain it during the 2016 elections, public opinion in favor of death penalty has reduced in recent years as well as the number of executions. According to the Death Penalty Information Center, 20 inmates 
were executed in 2016 which is the lowest since 1991when 14 were executed. Just five states accounted for these 20 executions in 2016; Alabama, Florida, Georgia, Missouri and Texas in contrast with 20 states in 1999

\section{U.S. executions at lowest level in 25 years}

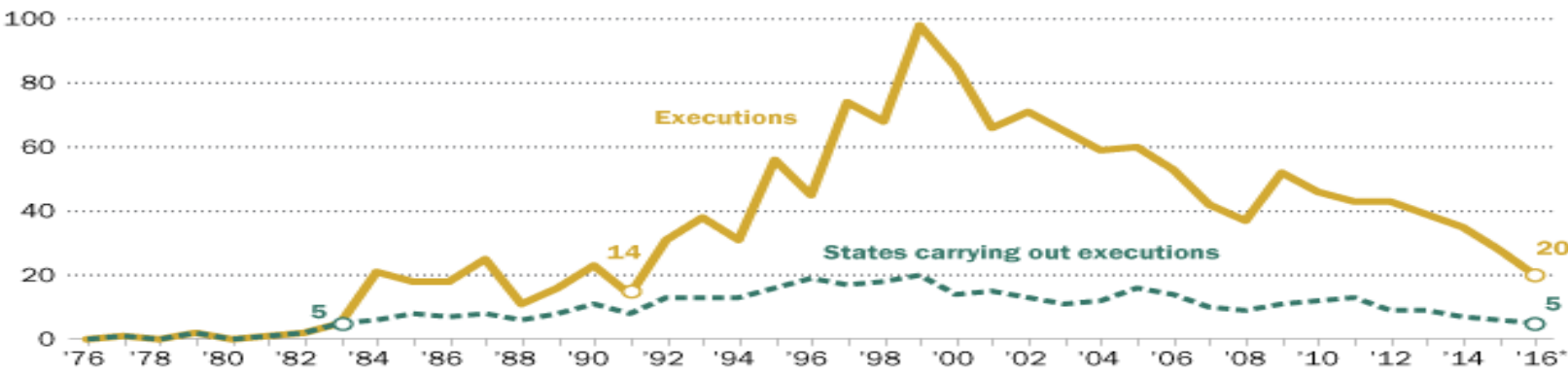

Notes: The federal government carried out two executions in 2001 and one in 2003. Source: Pew Research Center analysis of data from Death Penalty Information Center PEW RESEARCH CENTER

Source: Pew Research Center (2003). U.S Executions at lowest level in 25 years

Also, according to reports from Amnesty International, for the first time in a decade, America was not among the top five countries in executions in 2016 as it ranked $7^{\text {th }}$ internationally. More so, though more Americans still support than oppose the death penalty, this support has fallen dramatically in the past two decades

\section{Support for death penalty continues to fall}

$\%$ who __ the death penalty for persons convicted of murder

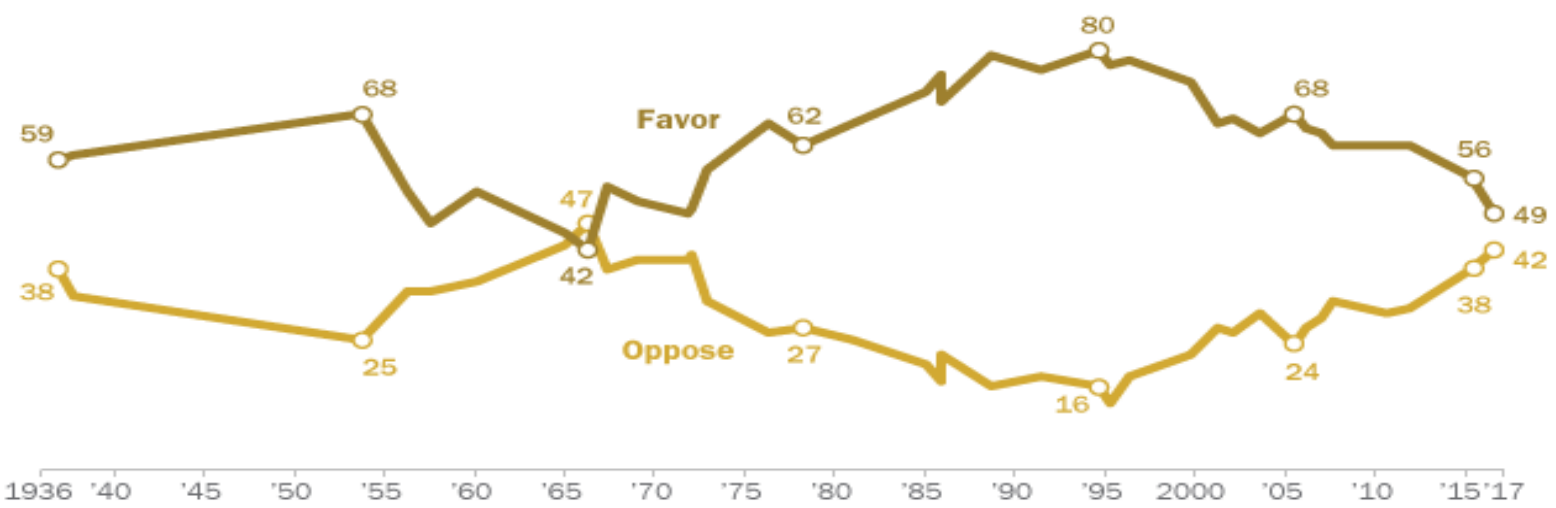

Notes: Don't know responses not shown. 1935-1995 data from Gallup.

Source: Survey conducted Aug. 23-Sept. 2, 2016.

PEW RESEARCH CENTER

Source: Pew Research Center (2016). Support for death penalty continues to fall.

\section{Alternative Recommendations}

Given the cruel nature of the death penalty and the affects that is has on the families of victims. It is important to discuss the need for sentencing reform, increasing programming and funding for jury education on life sentences and parole procedures, and increasing knowledge and awareness to the public on all the facets of the death penalty. Research shows that most people favor a sentencing of death over a sentence of life without parole. Dieter (1993) found that most people believe that with a life sentence there is a chance that a person could become eligible for parole and be released from prison and again become a threat to society. However, Dieter found that states that have used the sentence of life without parole says it works as promised. California for example, has had a sentence of life without parole for over 25 years and not one person sentenced under this law has been released from prison (Dieter 1993).

Similarly, in Louisiana, which has the nation's toughest life sentence law, life in the state of Louisiana is just that, life. In Louisiana life means natural life (Dieter, 1993). Juries serve as the voice of the people within the court systems. Their lack of awareness or lack of procedural and conceptual understanding can lead to wrongful sentencing practices. A study from the National Legal Research Group demonstrated the danger of uniformed 
jurors, where it was found that many jurors are sentencing people to death because they either lack adequate alternatives or because they are unaware that such alternatives exist (Dieter, 1993). This leads to executions based on misinformation, which is unjust. There needs to be increased training programs for America's juries in order to make sure that they are making informed sentencing decisions.

Scholars need to continue to research and disseminate knowledge of the death penalty to the public at large and to policymakers and stakeholders so that they can make informed policy decisions on the death penalty.

\section{Conclusion}

Conclusively, the death penalty is not merely considered as a cruel choice for punishment, it is seen as unethical and immoral by many. There is no reason to take away a life which you cannot give or did not give. The Creator of Humanity repented after destroying his own creations during the days of Noah in the Bible and as such no one has the right to take any human life. It is no form of justice because it does not bring any form of justice to the victim but creates more victims- family members of the executed. Many governments have substituted the death penalty with life imprisonment as a more humanistic method of punishment. The death penalty cannot be revoked if it was erroneously afflicted whereas imprisonment can be rectified by liberating the victim, if he is later discovered to have been innocent. There is equally no way a death person can be compensated for an erroneous death penalty sentence whereas an unjust imprisonment can be compensated with money. It is devastating to know that America who helped in drafting the Universal Declaration of Human Right (UDHR) after WWII and adopted it in 1948 does not respect its own creation. Nevertheless, despite the many organizations, agencies and religious bodies fighting against the death penalty; it still has a long way to go before its complete eradication.

\section{References}

Anon. 2012. "41 Federal Capital Offenses - Death Penalty - ProCon.Org." Retrieved February 23, 2019 (https://deathpenalty.procon.org/view.resource.php?resourceID=004927).

Anon. n.d. "A History of Ancient Greece." World History Center. Retrieved February 23, 2019a (http://historyworld.org/draco_and_solon_laws.htm).

Anon. n.d. "Death Penalty | Amnesty International." Retrieved February 23, 2019b (https://www.amnesty.org/en/what-we-do/death-penalty/).

Anon. n.d. "DEATH SENTENCE | U.S. Code | US Law | LII / Legal Information Institute." Cornell Law School. Retrieved February 23, 2019c (https://www.law.cornell.edu/uscode/text/18/part-II/chapter-228).

Anon. n.d. "Descriptions of Execution Methods | Death Penalty Information Center." Retrieved February 23, 2019d (https://deathpenaltyinfo.org/descriptions-execution-methods).

Anon. 2018. "Federal Death Row Prisoners | Death Penalty Information Center." Retrieved February 23, 2019 (https://deathpenaltyinfo.org/federal-death-row-prisoners).

Anon. n.d. "Methods of Execution." Retrieved February 23, 2019e (https://deathpenaltycurriculum.org/student/c/about/methods/lethalinjection.htm).

Bedau, Hugo. 1983. Bentham's Utilitarian Critique of the Death Penalty. Vol. 74.

Benthany, Jeremy. n.d. "An Introduction to the Principles of Morals and Legislation." The Library of Economics and Liberty. Retrieved February 23, 2019 (https:/www.econlib.org/library/Bentham/bnthPML.html).

Bohm, Robert M. 1999. Deathquest : An Introduction to the Theory and Practice of Capital Punishment in the United States. Anderson Pub. Co.

Du Bois, W. E. B. 2007. THE SOULS OF BLACK FOLK. edited by B. H. EDWARDS. OXFORD WORLD'S CLASSICS.

British Medical Association. 1992. Medicine Betrayed: The Participation of Doctors in Human Rights Abuses. London.

Catholic Charities. 2015. "Document: Pope Francis: No Crime Ever Deserves the Death Penalty." Retrieved February 23, 2019 (http://cqrcengage.com/ccdocle/app/document/6989268?0).

Cook, Matt, Robert Mills, Randolph Trumbach, and Harry Cocks. 2007. A Gay History of Britain : Love and Sex between Men since the Middle Ages.

Dandō, Shigemitsu. 1997. The Criminal Law of Japan : The General Part. F.B. Rothman.

Death Penalty Information Center. n.d. "Anesthesiologists Advised to Avoid Lethal Injections | Death Penalty Information Center." Retrieved February 23, 2019a (https://deathpenaltyinfo.org/node/297).

Death Penalty Information Center. n.d. "NEW VOICES: American Medical Association, EMT Association Say Participation in Executions Violates Medical Ethics | Death Penalty Information Center." Retrieved February 23, 2019b (https://deathpenaltyinfo.org/node/1775).

Dieter, Richard C. 1993. The Death Penalty and Human Rights: U.S. Death Penalty and International Law.

Ebenstein, William and Alan O. Ebenstein. 2000. Great Political Thinkers : Plato to the Present. Harcourt College Publishers.

Farah, Darlene. 2016. “My Daughter's Killer Should Not Get the Death Penalty.” Time. Retrieved February 23, 
2019 (http://time.com/4228181/florida-death-penalty/).

Fraser, Michael. 2010. Crime for Crime: Racism and the Death Penalty in the American South. Vol. 10.

Gabbidon, Shaun L. 2001. "W.E.B. Du Bois.” Journal of Black Studies 31(5):581-99.

Hall, Jim. 2016. "Commute All Death Sentences." Columbia Daily Tribune. Retrieved February 23, 2019 (https://www.columbiatribune.com/045535e0-f4a0-59d4-90bb-405fc0ceaaaa.html).

Hendee, David. 2016. "Death Penalty Opponent Says Her 'guilt Was Awful' after Men Convicted of Cousin's Murder Were Proven Innocent." Omaha World Herald. Retrieved February 23, 2019 (https://www.omaha.com/news/metro/death-penalty-opponent-says-her-guilt-was-awful-aftermen/article ab1dffe6-d3b8-5ef7-adaf-61077f98be20.html).

KCADP. 2012. "Family Members of Death Row Inmates: Another Group of Victims - Kentucky Coalition to Abolish the Death Penalty." Kentucky Coalition to Abolish the Death Penalty. Retrieved February 23, 2019 (https://kcadp.org/2012/02/23/family-members-of-death-row-inmates-another-group-of-victims/).

Muller. Robert. 2016. "Death Penalty May Not Bring Peace to Victims' Families | Psychology Today." Psychology Today. Retrieved February 23, 2019 (https:/www.psychologytoday.com/us/blog/talking-abouttrauma/201610/death-penalty-may-not-bring-peace-victims-families).

NAEMT. 2010. "New Position Statement Opposes EMS Participation in Executions." Retrieved February 23, 2019 (https://www.naemt.org/WhatsNewALLNEWS/10-0218/New_Position_Statement_Opposes_EMS_Participation_in_Executions.aspx).

Orthodox Church in America. n.d. "All-American Councils - The 9th All-American Council - Orthodox Church in America." Retrieved February 23, 2019 (https://oca.org/history-archives/aacs/the-9th-all-americancouncil).

Peffley, Mark and Jon Hurwitz. 2007. Persuasion and Resistance: Race and the Death Penalty In. Vol. 51.

Presbyterian Church USA. 2010. MINUTES 219th GENERAL ASSEMBLY. Louisville, KY.

Presbyterian Church USA. n.d. "Presbyterian Mission Agency Capital Punishment | Presbyterian Mission Agency." Retrieved February 23, 2019 (https:/www.presbyterianmission.org/what-we-believe/social-issues/capitalpunishment/).

Risher, Sharon. 2016. "My Mom Was Killed in the Charleston Shooting. Executing Dylann Roof Won't Bring Her Back." Vox. Retrieved February 23, 2019 (https://www.vox.com/2016/6/15/11894036/dylann-roofdeath-penalty).

Schabas, William. 2002. The Abolition of the Death Penalty in International Law. Cambridge University Press.

Sheehan, Paul. 2007. "Patriots Ignore Greatest Brutality.” The Sydney Morning Herald.

United Nations. 2018. "Third Committee Approves 11 Drafts amid Heated Debate over Death Penalty Moratorium, Use of Mercenaries, Efforts to End Cybercrime | Meetings Coverage and Press Releases." United Nations. Retrieved February 23, 2019 (https://www.un.org/press/en/2018/gashc4252.doc.htm).

United Nations Human Right. 2013. "\&quot;Hidden\&quot; Victims: The Children of Parents on Death Row." Retrieved February 23, 2019 (https://www.ohchr.org/en/newsevents/pages/hiddenvictims.aspx).

Vgoff. n.d. Capital Punishment.

Weisberg, Jacob. 1991. "This Is Your Death.” The New Republic 23-27.

Wright, John. 2009. "Rational Choice Theories." Oxford Bibliographies. Retrieved February 23, 2019 (http://www.oxfordbibliographies.com/view/document/obo-9780195396607/obo-9780195396607. 0007.xml).

Zimring, Franklin E. 2003. The Contradictions of American Capital Punishment. Oxford University Press. 